\title{
The religious origins of class \\ coalitions: elite participation in religiously motivated peasant rebellions in Mexico, Zimbabwe, and India
}

\author{
Vasabjit Banerjee \\ Indiana University, USA \\ University of Pretoria, South Africa
}

\begin{abstract}
This article explains why elite classes participate in religiously motivated peasant rebellions. This question is important because, although elite resources are required to overcome collective action barriers, extant research ignores why elites collaborate in religiously motivated peasant rebellions. The article compares the Moplah Rebellion in colonial India, the Cristero Rebellion in revolutionary Mexico, and the Chimurenga Rebellion in white-controlled Zimbabwe to test three common explanations for elite participation: low inequality between elites and peasants; moderate political repression or opportunity; and shared religious organizations with the peasantry. The findings demonstrate that elite cooperation is critically contingent on shared religion because it creates cross-class ideologies and lowers the costs of participation by elites. However, the effects of inequality of wealth and political opportunities are inconclusive. By doing so, the article introduces a theory of elite participation that can be tested and refined to understand ongoing religiously motivated rebellions in agrarian societies as disparate as Pakistan, Nigeria, and the Philippines.
\end{abstract}

\section{Keywords}

rebellion, religious movements, class coalitions, elites, collective identity, political opportunity, inequality, social movements, resource mobilization

\section{Introduction}

Why do elites participate in some religiously motivated peasant rebellions and not in others? Although elites provide resources critical to overcoming collective action barriers, existing research

\section{Corresponding author:}

Vasabjit Banerjee, Department of International Studies, Woodburn Hall, Room 316, Indiana University, Bloomington, IN 4740I, USA.

Emails: vbanerje@indiana.edu, vasabjit@gmail.com 
ignores why they choose to do so in peasant rebellions. Some scholars assume that elites are unimportant, focusing on peasant grievances and solutions to collective action problems (Scott, 1976, 2009). Others assume elite participation, focusing instead on why and how elites construct religious conflicts (De Juan, 2008; Wilkinson, 2006). Because elite support is one of the pivotal determinants of the success of rebellions, this article questions assumptions regarding elite behavior to explain the conditions under which elites participate.

Specifically, the article evaluates three explanations for elite class participation: first, elites participate when mass grievances related to inequality are low (Acemoglu and Robinson, 2006); second, elites participate under conditions of moderate repression or political opportunities (McAdam et al., 2009: 263); and, third, elites participate if they share a religion with the masses (Marwell and Oliver, 1993; Polletta and Jasper, 2001). The theories are tested by comparing three cases of such rebellions. In chronological order, these are the Moplah Rebellion from 1921 to 1922 in colonial India, the Cristero Rebellion from 1926 to 1929 in revolutionary Mexico, and the Chimurenga from 1972 to 1979 in white-dominated Zimbabwe.

The cases were selected because their different locations, cultures, and institutions highlight if the posited factors affect participation by elite classes. Generally known as 'Mill's Indirect Method of Difference', this research method combines maximal variance in the control variables and the dependent variables. It improves on Mill's Method of Agreement because it 'uses negative cases to reinforce conclusions drawn from positive cases' (Ragin, 1987: 39-42) by eliminating factors 'less likely to exercise a causal effect on the different outcomes since they appear in both' types of cases (Levi-Faur, 2006).

The findings show that elite participation depends on the existence of a shared religion with the peasantry. Shared religions integrate elites and peasants by creating a collective identity, while religious organizations provide resources that reduce costs for participating elites. Furthermore, the article demonstrates that variations in grievances based on inequality do not affect elite participation and moderate political opportunities are a constant, regardless of elite participation.

In terms of theoretical insights, the salience of shared religion reveals that 'religion' fosters or prevents rebellions independently of elite classes' preferences (Billings, 1990; Lewy, 1974). This finding challenges the contention that religiously motivated political violence 'is provoked by elites seeking to gain, maintain, or increase their hold on political power' (Fearon and Laitin, 2000: 846). Furthermore, the bottom-up nature of these rebellions challenges the characterization of peasants as passive and manipulable (Brass, 1997; Keddie, 1998; Woodward, 1995) by demonstrating that peasants' autonomous engagement with religion influences elite decisions.

The source materials for all three studies are mainly secondary, although they are supplemented with government documents from Mexican, Indian, and British archives. The sources were read with an eye toward the relative salience of grievances, opportunity structures, and religion vis-a-vis collective identity and collective action. Thus, the studies do not aim to provide a comprehensive picture of the rebellions. Gender, redistributive outcomes, and ideologies are largely ignored. Perhaps to some, such an approach would appear unfairly to underscore the salience of religion vis-a-vis material and secular interests; however, such an approach balances the relative neglect of religion in creating the class coalitions underlying peasant rebellions. Although the study of three cases is insufficient foundation for wide-ranging conclusions, the comparative analysis presented here reinterprets three often-studied cases to offer tentative conclusions that suggest broader applications to explain elite participation in rebellions in diverse developing societies such as the Philippines, Pakistan, and Nigeria.

In order to explicate the salience of the factors analyzed in the studies, the next section defines the phenomenon of religiously motivated peasant rebellions, explains why the participation of elite classes is critical to such rebellions' success, and, lastly, uses extant research to explain the 
relevance of the selected causal factors. This section is followed by studies of the Cristero, Moplah, and Chimurenga Rebellions, respectively, to test the posited theory's applicability. The concluding section summarizes the findings, explicates certain limitations, and suggests further avenues of research.

\section{Defining religiously motivated peasant rebellions}

This section first clarifies the notion of religiously motivated peasant rebellions. The goal is to define religion before characterizing religiously motivated rebellions. The role of elite classes and peasants in such rebellions is subsequently explicated to show why elites are crucial in determining the rebellions' success. The second half of the section defines and explicates the role of grievances, political opportunities, and shared religious organizations in such rebellions.

What is religion? Based on existing research, I define religion as a three-dimensional concept encompassing a set of ideas, a community of believers, and religious elites or organizations. The first and second dimensions of religion are a set of ideas and a lived community (Appleby, 2000). Ideationally, religion provides 'beliefs and values concerning the ultimate origin, meaning, and purpose of life', which 'find official expression in doctrine and dogmas' (Appleby, 2000: 8). The lived community is defined by shared rituals, such as prayers and devotions, which express these ideas, and by following 'the explicit moral norms governing the behavior' of those belonging to the religion (Appleby, 2000: 9). The third dimension consists of religious organizations, such as churches, networks, and related religious actors (Basedau and Vullers, 2010: 3), and religious elites whose interests are distinct from believers (De Juan, 2008; De Juan and Vullers, 2010: 7).

Religious ideas can increase the initiation and intensification of conflicts. The dichotomous notion of 'good and evil' makes religious values indivisible and, consequently, incapable of being rationally bargained and compromised to avoid conflicts (Hasenclever and Rittberger, 2003; Svensson, 2007; Toft, 2007: 100). Once conflicts begin, the notion of martyrdom undermines costbenefit analyses underlying the curtailment or cessation of violence, thus increasing the duration of conflicts and their recurrence (Appleby, 2003; Hasenclever and Rittberger, 2003; Toft, 2007: 101).

This article comprehends religious grievances' legitimation of conflict as akin to Hasenclever and Rittberger's characterization of the constructivist approach (2003): that grievances related to religion either act alone or in conjunction with grievances arising from political and economic marginalization. Acting alone, religious grievances extend from demands against the state to practice a religion freely to demands that one particular religion dominate state institutions. Religion, however, can also be used to frame notions of injustice and tyranny, to assign responsibility to individuals and groups for these problems, and, subsequently, to provide resolutions such as rebelling to defend religious beliefs or capturing the state (Benford and Snow, 2000: 615). In terms of the selected cases, religious and material grievances can overlap, as in the Chimurenga Rebellion in Zimbabwe and the Moplah Rebellion of India. Concomitantly, religious grievances may overwhelm material preferences, as in the Cristero Rebellion of Mexico.

Furthermore, religious organizations provide intangible and tangible resources that facilitate the initiation and sustenance of conflicts (De Juan, 2008). Religious organizations' role in overcoming collective action barriers is highlighted in studies of peaceful mobilizations, such as that of the black church in the US civil rights movement (McAdam, 1982; Morris, 1984), and anti-authoritarian movements (Garcia and Parker, 2011; Hank and Figa, 1988). In all three cases studied here, religious organizations supported rebelling peasants.

The above definitions raise the question of which social classes participate in such rebellions. In order to succeed, religiously motivated rebellions require the collaboration of elite classes who provide resources, such as information, leadership, and finance (McCarthy and 
Zald, 2006), with peasants who compose the majority of the agents that carry out the rebellion. Elite classes can be divided into groups owning land (landowners or landlords) or capital (the bourgeoisie or middle classes), while the peasants own only their labor (Boix, 2003). Along with different resources, the social classes also differ in size: in agrarian societies, peasants are most numerous, while elite classes are small. Consequently, the peasantry's large size and poverty interacts with the need for resources to overcome collective action barriers to necessitate collaboration with elites.

As a caveat, although an individual's membership of a class is primarily contingent on the type of assets that he or she controls, this article nuances actual categorization of individuals or groups within a class by historical research and self-identification. Thus, in some areas, groups owning small parcels of land can self-identify as peasants, while scholars classify landless agricultural laborers as peasants in other areas. Similarly, the bourgeoisie or middle classes can extend from moneylenders and storekeepers who also own land to merchants exporting cash crops or owning urban businesses. Landowners or landlords in some societies are little more than landed farmers, or have seigniorial rights or grow cash crops on vast lands.

As demonstrated by the individual studies, all the selected cases fit these definitions and conditions. The success of the Cristero Rebellion depended on collaboration between peasants and the bourgeoisie, while the Chimurenga Rebellion's success depended on collaboration between the black landowners and bourgeoisie with peasants. Conversely, elites did not participate in the Moplah Rebellion, which contributed to its failure.

The above explication of classes in agrarian societies leads to the article's central puzzle of why elite classes choose to participate in religiously motivated rebellions. After all, such elites stand to lose the most materially, while also gaining relatively little. The empirical studies demonstrate that elite participation depends on sharing a religion with the peasants. Specifically, shared religion induces elite participation by fostering a collective identity with peasants and providing resources that reduce the costs of participation for elites.

The studies also test for two alternative explanations prevalent in the study of peasant rebellions: the existence of opportunity structures and inequality of wealth. Specifically, elite classes choose to participate under conditions of moderate to low inequality and moderately open or repressive political structures. The rest of the section, therefore, uses extant research to clarify the concepts of religious organizations, political opportunity, and inequality, and briefly states whether the studies validate their role in such rebellions.

This article's central hypothesis is that religion plays a critical role by expressing and symbolizing its members' collective identity, as well as providing resources such as organization, finance, and leadership (Tilly, 1978: 84). The studies demonstrate that the pivotal contribution of shared religious organizations is their creation of solidarity between elite classes and peasants and the provision of resources that reduce the elites' costs of participation. However, separate religious identities can create exclusive groups within and between elite classes and peasants; under such conditions, provision of resources by religious organizations is ineffectual.

Shared religion integrates elite classes and peasants in ways that belie the rational calculus of interest by providing common perceptions of a 'shared status or relation' that 'may be imagined rather than experienced directly', and 'distinct from personal identities, although it may form part of personal identity' (Polletta and Jasper, 2001: 285). These emotional ties encourage and enforce participation via norms of duties and responsibilities or mutuality and obligation (Marwell and Oliver, 1993; Oberschall, 1973). Study of the Cristero and Chimurenga Rebellions shows the existence of cross-class collective identities based on Catholicism and the indigenous Shona religion, respectively. Conversely, elite classes and peasants did not share a religion in the Moplah Rebellion: generally, peasants were Muslims and elites were Hindus. 
Other than providing a shared collective identity, scholars recognize that religious organizations contain social networks, organizational structures, and funds encouraging participation and discouraging defection or opposition within communities of believers (Garcia and Parker, 2011; Hank and Figa, 1988). All three studies extend these insights by demonstrating that the contribution of resources by religious organizations also affects participation by elite classes. Indeed, despite significant variations in the degree of doctrinal flexibility and institutional hierarchy, the Catholic clergy in Mexico and the Shona spirit-mediums of Zimbabwe both provided valuable help to rebels.

This article also addresses theories of 'opportunity structures', which posit that people rebel upon perceiving changes in political and economic institutions that affect 'the degree to which groups are likely to be able to gain access to power and to manipulate the political system' (Eisinger, 1973: 25). Specifically, apertures in formal institutions, and consequent rebellions, occur when existing institutions are threatened by instability in alignments between incumbent elites, the development of multiple independent centers of power within a regime, and a decline in the state's capacity for repression (McAdam et al., 2009: 263).

Based on the classification of elitism, moderate repression, extreme yet incomplete repression over time, divided elites, and political instability suggested by Williams (1994), the studies show that intermediate levels of opportunity were a constant precursor to peasant rebellions. Colonial India and white-dominated Zimbabwe (then Rhodesia) were elitist regimes that moderately repressed the nonparticipating native populations. The majority of the populace in colonial India and revolutionary Mexico also enjoyed moderate political freedoms. Revolutionary Mexico was also characterized by extreme, yet incomplete repression by the central state between 1915 and 1935, accompanied by elite divisions and political instability. However, such conditions did not determine elite participation. Elites participated in the Cristero and Chimurenga Rebellions, but did not partake in the Moplah Rebellion.

Furthermore, the article tests theories positing inequality of wealth as the critical determinant of elite participation. In this vein, Daron Acemoglu and James Robinson (2006) argue that elites support rebellions in societies characterized by lower inequality because the masses' redistributive goals are compatible with the elite classes. In other words, elite classes do not support rebellions in societies characterized by high inequality.

However, the studies show that the effect of inequality on elite participation in religiously motivated mobilizations is inconclusive. Specifically, lower inequality increases participation by elite classes in the Cristero Rebellion. Yet, high inequality coexists with elite nonparticipation in the Moplah Rebellion, while similar conditions encouraged elite participation in the Chimurenga Rebellion. On this note, the studies reveal that grievances related to land, the primary resource in agrarian societies, cannot singly explain peasant participation. Specifically, they show that in the Moplah and Chimurenga Rebellions, peasant grievances vis-a-vis land rent and control were high. However, peasants participated in the Cristero Rebellion despite enjoying freer access to land, which relatively lowered grievances.

Although they are used to verify the existence of the posited causal factors, the following three case studies are narrated based on their specific internal logic. As represented in Table 1, every study includes the following elements: the initial grievances; initial opportunity structures; whether religious organizations fostered a cross-class collective identity; and whether the respective religious organization resolved collective action problems.

\section{The Cristero Rebellion: elite commitment for land and God}

The Cristero Rebellion in central-western Mexico was unlike the country's contemporaneous rebellions. Beginning in 1926 and ending in 1929, the Cristero Rebellion occurred after the violent 
Table I. Causes of Elite Participation.

\begin{tabular}{lllll}
\hline Cases & $\begin{array}{l}\text { Grievances: } \\
\text { inequality }\end{array}$ & $\begin{array}{l}\text { Political } \\
\text { opportunities }\end{array}$ & Shared religion & Elite participation \\
\hline Cristero & Low & Moderate & Yes & Yes \\
Moplah & High & Moderate & No & No \\
Chimurenga & High & Moderate & Yes & Yes \\
\hline
\end{tabular}

phase of the Mexican Revolution (between 1910 and 1920). More importantly, it was fought to defend the rights of the Catholic Church against the incumbent revolutionary regime, and received support from the elite classes and peasants. Thus, although nearly 60 percent of those mobilized were landless agricultural laborers and 15 percent rented their land, nearly 14 percent of Cristeros belonged to the rural middle class (Mabry, 1978).

Despite extant grievances related to the control and ownership of land, these were not apparently the pivotal factor for elite participation or peasant rebellion. In terms of elite classes, the bajío region, covering the central-western states of Guanajuato, Michoacán, Queretaro, and Jaliso, is covered with mountains interspersed with valleys that contained a large number of landowners owning homesteads. This created an agrarian bourgeoisie, and a small urban middle class directly and indirectly involved in commercial agriculture (Brading, 1975: 131). In Michoacán, Purnell (1999) notes that the cattle-owning ranchero rural bourgeoisie existed in the 'coastal highlands' and much further inland near the 'northwest highlands' around Lake Chalapa. In the highlands region of Jalisco, called Los Altos, the poor soil type was ideal for cattle ranching, and attracted emigrants from Europe who maintained their lands and social ties by endogamy (Navarro, 2000-01: 30-31, 51-5). Alongside the rural and urban bourgeoisie, there also existed large-hacienda-owning landlords, akin to the rest of Mexico (Brading, 1975; Purnell, 1999). However, despite the ethnic and economic differences within elites, pre-revolutionary institutions had uniformly supported the private ownership of land versus communal control of the land; thus favoring the rural bourgeoisie and the landlords at the cost of surrounding indigenous villages (Hubert, 1988).

Although the property rights institutions supported the elites, conditions for landless laborers and the indigenous peasant communities were also better than in other parts of Mexico (Sanderson, 1984: 33). In fact, where indigenous peasant communities felt deprived by local landlords, as in central and southern Jalisco, they fought against the Cristeros in order to gain the revolutionary government's support against their landlords (Navarro, 2000-01: 21, 27, 38, 45).

Unlike inequality, changes in political-economic structures that threatened to deprive the peasants of autonomy appear to have contributed to the rebellion. In this sense, it was the actual inability of the revolutionary government to repress local opposition (a condition of moderate repression) combined with the perceived threat of future repression that propelled the rebellion. According to Jaime Tamayo (2008), the initial peasant uprisings were based on the realization that acceptance of land grants from the revolutionary government would mean surrendering their control over land. Such economic co-optation, it was further feared, would result in political subjugation to the revolutionary regime (Purnell, 1999: 184-91).

The Liga de Comunidades Agraristas del Estado de Jalisco, for example, aimed to protect indigenous peasants from landlords and break up the large haciendas. Yet, it was soon integrated into the Confederacion Regional Obrera Mexicana (CROM), one of the official unions of the national regime (Tamayo, 2008: 109-10). Furthermore, peasant beneficiaries in Aguascalientes were also forced to fight for the national government against the Cristeros (Archivo General de la Nación, no 
date a: 17; no date b: 36-7). Navarro (1985: 49) also notes that such forced conscription prevailed in most affected areas.

However, the critical factor determining elite class participation was the Catholic Church, which provided a cross-class collective identity that increased trust among the elite classes and peasants as well as leadership and finances that reduced the participating elites' costs. The church played these dual roles because the Mexican church was a bi-layered institution: on the one hand, its central tenets and principles came from the Vatican and were imposed by a bureaucracy under the bishoprics (Wilkie, 1966); on the other hand, the laws and governance were instantiated in myriad small churches embedded in and responsive to regional villages and towns (Butler, 2006). The centralized church bureaucracy propounded a cross-class ideology of how religious freedom was being threatened by the revolutionary regime (De Bonfil, 1966; Meyer, 1974: 295, 303), while local church institutions empowered the church to create lay associations centered on religio-civic activities, such as the Liga Nacional para la Defensa de las Libertades Religiosas (LNDLR) and the Asociación Católica de la Juventud Mexicana (ACJM), which united bourgeois elites and increased interactions and trust between them and the peasantry (Butler, 2004).

The Catholic Church's support of the rebellion was neither unprecedented nor altruistic. The Catholic Church and the Mexican state had been opposed to each other since the civil wars in the mid-19th century between pro-church conservatives and secular liberals (Bailey, 1974; Meyer, 1974). The revolutionary government had always been aware of potential opposition from the Catholic Church. Consequently, the government forbade church participation in politics and subjected it to secular laws through Article 130 of the Mexican Constitution. Nevertheless, prior postrevolutionary governments under Presidents Carranza and Obregon were unwilling and unable to enforce these laws (Tamayo, 2008: 117-32). However, the more powerful revolutionary government under President Calles and its local representatives, such as Governor Zuno in Jalisco, attempted to consolidate power by enforcing these laws (Aceves, 2009). Given government repression and its social power, the church cemented a coalition between the elites, who provided leadership and finance along with the church, and the rebellious peasants (Butler, 2006; Meyer, 1976).

The urban bourgeoisie participated in the rebellion by providing financial support and political leadership via the LNDLR and the ACJM (Bailey, 1974: 304). Specifically, the LNDLR created the Special War Committee, and attempted to manage the Cristero rebels (Bailey, 1974: 114). Capistran Garza of the LNDLR visited the USA on an unsuccessful mission to garner financial and political support for the rebels (Bailey, 1974: 122). Elites in other similar organizations, such as the Union Popular, provided urban hideouts for the rural rebels (Meyer, 1976: 128), collected money, provided supplies, and propagated the rebellion (Purnell, 1999: 101), while women members of the Brigadas Femininas smuggled ammunition to the rebels (Miller, 1984: 315-6).

In the rural battlefields, the peasants were led by ranchero political bosses, who were once powerful all over Mexico. For such warlords as Ladislao Molina, religion functioned as both a means and performance of their dominance over the local political economy (Butler, 1999). Akin to the peasants, the revolutionary regime's land-redistribution policies and the introduction of peasant collectives connected to the regime also threatened the power of the bosses. Thus, they participated in a rebellion of landless and small-holding peasants (Ankerson, 1984: 122-3).

Participation by the urban and rural bourgeoisie and the church created a rebellion that was only pacified via negotiations in 1929. The elite classes and the church acquired major concessions from the government. The elite classes were permitted to have political representation in a recognized party, which later developed into the Partido Acción Nacional (Meyer, 1976: 67-75). The revolutionary regime recognized the church's position in Mexico via the Modus Vivendi pact (Reich, 1997). To mollify the peasants, the revolutionary government increased land redistribution during and after the end of the rebellion (Sanderson, 1984: Fig. 5.3). However, the simultaneous 
introduction of peasant collectives, called ejidos, also co-opted peasants into the revolutionary regime (Ankerson, 1984; De Bonfil, 1966; Fabregas, 1977).

\section{The Moplah Rebellion: divided religions and elite opposition}

Although motivated by religion, the Moplah Rebellion of 1921-22 in the coastal Malabar region of the southern Indian province of Madras failed to attract support from elite classes and was, subsequently, crushed by the British. Unlike the Cristero Rebellion, the Moplah Rebellion had a background of peasant grievances regarding land rent paid to the government and landlords. However, similar to the political conditions in Mexico under which the Cristero Rebellion occurred, political opportunity structures appeared to change with the first anticolonial mass mobilization. The rebellion nevertheless failed because religious organizations centered on Islam alienated the elite classes: it neither attracted elite co-religionists nor Hindu elites.

The peasants' grievances arose from the structure of land ownership and revenue collection. Land in the Malabar region was historically owned by upper-caste Hindus (generally Brahmin) called janmi, but cultivation and revenue collection were managed by Hindus from the Nair caste called kanam. The British recognized the janmi as the permanent leaseholders of land from the government: the janmi directly paid assessed revenue to the government; could sublet their property or 'transfer it by gift, sale, or mortgage'; had the right to retain such land as long as they paid the revenue; and could increase or decrease their holdings or entirely abandon them (Mill, 1859: 241). In contrast, the peasant cultivator became entitled to a third of the produce (Krishnan, 1993: 110).

Due to the British favoring of the 'natural' rights of the janmi and kanam (Logan, 2004: 608), the Malabar region became characterized by high land rents and conflictual relations between landlords and peasants (Francis, 1908: 340). Inequality of wealth also increased, as lands became concentrated in the hands of the janmi and kanam. Conrad Wood (1987: 141) compares the Censuses of India from 1901 and 1911 to show that whereas landlords constituted 5.7 percent of the population employed in agriculture in 1901, they were 5.1 percent of the population in 1911 (see also United Kingdom, Government of India, 1903: 231-3; 1913: 140-2). During the same period, the percentage of agricultural laborers went from 61.8 percent to 60.7 percent of the population. Thus, the relative concentration of land ownership was much higher than improvement among agricultural laborers. British administrators analyzing the causes of the rebellion noted the poverty that characterized the Moplah peasants' existence, though they subsequently imputed [calculated?] that poverty made the Moplah ignorant and manipulable by outside agitators (Hitchcock, 1925: 9), rather than considering the peasants' grievances.

Simultaneously, the Malabar region also witnessed changes in political opportunities of local and national provenance. At the local level, there was conflict between the kanam and janmi. The kanam became members of the Indian National Congress (INC) party to enhance their control over land vis-a-vis the janmi (Panikkar, 1978: 885-6). The Justice Party movement, then dominating provincial politics, was led by the middle class, whose grievances centered on the disjuncture between their enhanced economic power and low status (Barnett, 1976: 15-31).

From the national level there arose in 1920 the first Gandhian mass mobilization, called the Non-Cooperation and Khilafat movement because it merged the mainstream anticolonial mobilization with the Islamic movement to restore the Ottoman Caliph. Between June and August 1921, the INC created local Khilafat committees to appeal directly to the Moplah peasants' Islamic faith to start a movement to restore the Caliph (Brown, 1972: 328). However, the control exerted by the INC over recruits' activities was minimal, as 'itinerant organizers would visit a desam (village), hold a meeting in the local mosque, collect subscriptions, appoint Khilafat officials, and pass on, 
hardly knowing who their new recruits were' (Wood, 1987: 141). Although the Khilafat movement combined religious with political grievances, such appeals also tapped into pre-existing panIslamic ideologies that had precipitated prior revolts led by local Muslim clerics (Alavi, 2011; Dale, 1977). The district magistrate of Malabar noted the involvement of senior Muslim clerics in Khilafat meetings and attempted to stop further meetings (Thomas, 1921).

However, whereas pan-Islamism encouraged Moplah peasant participation, it alienated possible elite-class supporters. The Islamic ideology spurring the rebellion centered on mosques providing communication networks and local leadership via clerics (Hitchcock, 1925: 3). Yet, Islamic leaders also framed the conflict as a jihad against the British Empire and its local allies, the Hindu janmi and kanam (Panikkar, 1989; Randathani, 2007: 138-46). The divisions fostered by religion alienated the Hindu elite classes. The effect of this was worsened because the wealthier landowning and middle-class Moplahs from northern Malabar also did not rebel (Hardgrave, 1977: 97-8).

The unsuccessful peasant rebellion of 1921 was characterized by extreme violence. It led to the killings of British officials and soldiers, along with rapes and the looting of Hindu property, the killing of Hindu landlords, and the forcible conversion of Hindu peasants (Nair, 1923: Appendix, 52-72). However, it was crushed rapidly and the peasants did not achieve their objectives of lowering land rents and changing the system of land ownership. Instead, the British passed the Malabar Tenancy Act, rewarding the middle classes for nonparticipation by granting more rights to the kanam relative to the janmi and Moplah peasants (Panikkar, 1978: 887). The middle classes continued in power via the Justice Party until the mid-1930s and, subsequently, through the INC - both of whose primary function was to tap jobs and resources from the provincial government (Washbrook, 1973: 525-7).

\section{The Chimurenga Rebellion: spirits of elite collaboration}

The Chimurenga Rebellion began in the mid-1960s with the adoption of armed struggle by the Zimbabwe African People's Union (ZAPU) and then the Zimbabwe African National Union (ZANU). Both ZAPU and ZANU were led by educated socialist urban leaders seeking to replace the white-settler-controlled Rhodesian regime with a modernizing regime representative of the interests of the black African majority (Scarnecchia, 2008). Yet, whereas ZANU transformed itself into an organization of full-fledged peasant rebellion based upon these grievances, ZAPU continued to rely on guerrillas generally recruited from urban areas (Brickhill, 1995).

I argue that the ZANU-led rebellion's success is not fully explainable by grievances or political opportunities and repression. Rather, the rebellion encompassed peasants and elite classes because of the role of the mhondoro, that is Shona spirit-mediums. ZANU and ZAPU had similar grievances against the British colonial and the subsequent white Rhodesian regimes: lack of land for indigenous peasants, few urban economic opportunities, and political exclusion. Out of these, the lack of arable land was the most important because the largest (relative to the population) and most fertile tracts were occupied by a small minority of white settlers, while the majority blacks were permitted usufruct rights in small (relative to the black population) and less fertile communal reservations called Tribal Trust Lands (TTL) or private ownership in African Purchase Areas (APA).

These grievances were rooted in the origins of the Rhodesian regime, which began as the British (white) settler colony of Southern Rhodesia and achieved responsible government in 1923 under white minority rule. Between 1953 and 1963, it unified with Northern Rhodesia (present-day Zambia) and Nyasaland (present-day Malawi) in an unsuccessful strategy to stave off black majority rule (Franklin, 1963). Soon after the collapse of the union, Southern Rhodesia unilaterally declared independence because Britain refused to grant it independence without the introduction of black majority rule (United Kingdom, 1963). During this time, laws and regulations regarding 
politics and race relations remained undisturbed or became stringent (United Kingdom, 1966). Consequently, black Africans continued to be aggrieved about their disenfranchisement and the lack of land reforms (Meredith, 1980: 91-106). Furthermore, active repression of political opposition increased through the mid-1960s via a series of laws and regulations (Palley, 1970).

Yet, the lack of change in political institutions did not lead to the success of ZANU and ZAPU guerrillas. Initial attempts at guerrilla warfare from 1965 to 1968 failed because, besides the guerillas' lack of training and coordination, peasants refused to join the forces and peasant communities withheld support (Lohman and MacPherson, 1983). The underlying problem was ZANU's inability to attract sympathy and support from the rural population, namely, the rural elite classes and the peasants (Mazarire, 2011).

This problem was resolved when ZANU allied with Shona spirit-mediums, broadly classified as svikiro (the plural of which is masvikiro), in the early 1970s. Usually men, the spirit-mediums were the principal representatives of the Shona agro-cosmological religion, which sought to harmonize the rhythms of nature, human society, and the spirit world (Lan, 1985; Schoffeleers, 1978). According to this agro-cosmological religion, the real owners of the land are the autochthonous spirits 'who intervene in the management and utilization of land' via mediums; the people only govern that land on behalf of the spirits - a connection instantiated by the overlapping of the agricultural and spiritual calendar (Sadomba, 2013).

During the time of possession (but usually beyond that) the spirit-medium is referred to as mudzimu, if they represent ancestral spirits, or mhondoro, if channeling the spirits of ancient chiefs and heroic warriors. The process of recognizing a person as a svikiro involves acceptance and initiation by existing mhondoro and tribal elders; once initiated, the individual svikiro may lose legitimacy with the public (Fry, 1976). Due to their higher position in the spiritual hierarchy, this study focuses on the mhondoro.

Given acceptance by elders and other mediums, and with public legitimacy, a mhondoro provides authoritative opinions and judgments on matters extending from familial disputes to political decisions and, most importantly, regarding agriculture, such as when to plant and harvest and on the possibility of rain (Bourdillon, 1976). The ability of mhondoro to accomplish these tasks actually depended on their knowledge of local events and persons. Consequently, divination frequently led to patients being diagnosed as the victims of witchcraft by their enemies or as losing the protection of ancestral spirits (mudzimu) because of harming kith and kin (Fry, 1976; Lan, 1985).

As the colonial and then white-controlled Rhodesian regimes co-opted the indigenous chiefs, using the strategy of indirect control, the mhondoro remained an autonomous institution whose power remained contingent on support from all segments of society (Fry, 1976: 120). The ability of the mhondoro to deter dissension among the Shona and threaten collaborators of the Rhodesian regime made them attractive allies for the urban Shona bourgeoisie who dominated ZANU at the national level (Scarnecchia, 2008).

The demand for such services increased as guerrilla advances and the Rhodesian regime's retreat from rural areas threatened to fragment Shona society on the lines of class, gender, and age. Poor peasants, youths, and women from the Zimbabwe National Liberation Army (ZANLA), ZANU's military wing, challenged and coerced the wealthy older men who held power (Kriger, 1988). In this context, the mhondoro's knowledge of local affairs and legitimacy enabled him to punish dissenters and collaborators by labeling them as witches, excommunicating them, and exacting fines (Latham, 1986: 66-75). The mhondoro mediated relations between ZANLA and the rural population, by imposing restrictions on guerrillas regarding sexual relations with local women and helping guerrillas to avoid detection and to take advantage of local terrain (Lan, 1985: 164-5).

Given the shared background and ideology of the mhondoro, rural elites attended possession ceremonies with peasants and abided by the imposed strictures regarding goods and services (Lan, 
1989). The mhondoro appealed to Shona landowners, who dominated politics in the communal TTL or owned land in areas designated for blacks called Purchase Areas, because mhondoro ideology blamed the deprivation of land on the white-controlled regime, rather than on internal differences (Ranger, 1985: 264-5, 269). Landowners' support was also incentivized because they expected future access to individual mhondoro if such individuals were to become politically and economically powerful (Byers et al., 2001; Spierenburg, 1995).

Familial ties between landowners and the mhondoro also engendered cooperation. Fry (1976: 68-106) notes that his assistant, who subsequently became a spirit-medium among the Zezuru subgroup of the Shona, belonged to a family owning cattle and land in the TTL and an urban transportation business. Lan (1985: 60-62) notes that the mhondoro among the Korekore subgroup relied upon intermediaries called mutapi from locally established families.

The rural elites directly helped the ZANLA guerrillas by providing food, clothing, blankets, and washing facilities (Reid-Daly and Stiff, 1982: 325-7; Machingura, 1977:17 ; Maxwell, 1993: 368). The resulting alliance transformed the small disorganized groups of ZANLA guerrillas lacking local support that were easily killed or captured in the mid-1960s (Ranger, 1997). By the late 1970s, better trained ZANLA guerrillas used local support to combat Rhodesian forces to an extent whereby large areas became 'liberated zones' (Godwin and Hancock, 2008: 245, 251; Lohman and MacPherson, 1983: 46-50). After political maneuverings by ZANU and ZAPU, the Rhodesian government, and a host of other countries, black majority rule was achieved by 1980 under the leadership of Robert Mugabe of ZANU (Preston, 2004).

\section{Conclusion}

This article explains why elite classes participate in religiously motivated peasant rebellions by testing three hypotheses. First, elites participate if peasants have a low level of grievances regarding inequality of wealth, specifically, control over land. Second, elites participate due to changes in political opportunities, particularly if repression is moderated. Third, elite classes participate if they share religious organizations with the peasantry because religion fosters a common identity and lowers the costs of collective action.

Studies of such rebellions in three very different societies demonstrate the salience of shared religious organizations in determining elite participation. In contrast, inequality cannot explain elite participation: it is high in the failed Moplah case; high in the successful Chimurenga case; and, low in the successful Cristiada case. Similarly, political opportunities are demonstrated to be a constant (and moderate) in all three cases and, therefore, cannot explain elite participation.

This article takes a first step in creating a theory explaining elite participation in religiously motivated peasant rebellions. Although I do not comprehensively explain why rebellions succeed, elite participation is an important factor that determines the success of rebellions. Thus, future research can test and refine (or discard) the model presented here by applying it to comparable cases, broadening the theory by addressing associated concepts and addressing the limitations of this article's research design imposed by time and funding constraints.

In terms of comparative implications, this article's findings can be corroborated by at least three ongoing religiously motivated rebellions in developing societies: in the Philippines, Nigeria, and Pakistan. Despite the salience of grievances regarding economic and political exclusion, the brief explications presented below suggest the importance of a shared religion in garnering popular support for these rebellions.

With regards to the Moro Rebellion in the Philippines, my theory accounts for Muslim Filipinos' grievances against political and economic marginalization by the Christian-dominated central government (Montiel and Macapagal, 2006). Furthermore, my findings dovetail with 
McKenna's anthropological study (1998) that highlights the long-standing religious solidarity, centered on Islam, between the local middle-class elites and poor citizens on the island of Mindanao.

Similarly in Nigeria, latest insights suggest that the violent Boko Haram movement enjoys support from economically marginalized citizens and the local middle class, extending from professionals to businessmen (Agiboba, 2013; Uadiale, 2012). Despite grievances centering on marginalization by the westernized elites who dominate the central government, Islamic revivalism has been central to the development of a collective identity between the Muslim middle classes and the poor (Abimbola, 2010). Furthermore, evidence suggests that a network of mosques have acquired funds from Saudi Arabian Salafist groups and are indoctrinating refugee youths from neighboring Chad (Walker, 2012: 3).

Regarding Pakistan, the theory presented here dovetails with both the bottom-up argument that political-economic marginalization of the rural populace by feudal landlords has increased popular support for Islamic militancy (Sareen, 2010) and the top-down argument that dissenting elites support the imposition of Islamic laws and regulations (Behuria, 2010). Moreover, Islamic charities channel foreign funds and mosques indoctrinate poor youth (Gómez, 2010; Stern, 2000). Based upon this article's explanation, such a combination of factors can facilitate the formation of a revolutionary class coalition.

In terms of associated concepts, future research can consider the additive and interactive effects of ethnicity, nationalism, and religion (Hastings, 1997; Smith, 2003) in explaining class alliances. Furthermore, research in this vein can address the broader debate on whether popular movements for political representation and social justice are propelled by enlightened rationality or beliefs in universal 'natural' rights (Kenny, 2004; Ratzinger and Habermas, 2007).

In terms of research design, this article utilizes an elementary design that compares evidence regarding the existence of the posited causal factors on coalitions between peasants and elites. The article simply intended to show why elite classes, regardless of whether they are the bourgeoisie or landlords, ally with peasants. Future research should, therefore, account for the effects of intra-elite competition. For example, it could examine the role of military servicemen with official land grants in the north-western colonial Indian province of the Punjab (Yong, 2005) and of those in the Austro-Hungarian Balkan border regions (Franke, 2002: 34; Lampe, 2000: 30), both areas where religiously motivated rebellion has a long history.

Lastly, the reliance on secondary sources and the need to present the study within an articlelength project prevented comprehensive explication of the processes by which the posited factors affected the elite classes' decisions to rebel. Future book-length research can use archival sources and interview participants and survivors to reveal these decision-making processes.

\section{Funding}

This research received no specific grant from any funding agency in the public, commercial, or not-for-profit sectors.

\section{Note}

1. I would like to thank Drs. Andries Bezuidenhout, Irma DuPlessis, Janis Grobbelaar, Jonathan Hyslop, and Mr Splagchna Chikarara.

\section{References}

Abimbola, Adesoji (2010) The Boko Haram uprising and Islamic revivalism in Nigeria. Africa Spectrum 45(2): 95-108. 
Acemoglu, Daron and James Robinson (2006) The Economic Origins of Dictatorship and Democracy. New York: Cambridge University Press.

Aceves, Maria TF (2009) José Guadalupe Zuno Hernández and the revolutionary process in Jalisco. In: Buchenau, Jurgen and William H Beezley (eds) State Governors in the Mexican Revolution, 1910-1952: Portraits in Conflict, Courage, and Corruption. Lanham, MD: Rowman and Littlefield, pp.95-108.

Agiboba, Daniel E (2013) Why Boko Haram exists: The relative deprivation perspective. African Conflict and Peacebuilding Review 3(1): 144-57.

Alavi, Seema (2011) Fugitive mullahs and outlawed fanatics: Indian Muslims in nineteenth century transAsiatic imperial rivalries. Modern Asian Studies 45(6): 1337-82.

Ankerson, Dudley (1984) Agrarian Warlord. Dekalb: Northern Illinois University Press.

Appleby, R Scott (2000) The Ambivalence of the Sacred: Religion, Violence, and Reconciliation. Lanham, MD: Rowman and Littlefield.

Appleby, R Scott (2003) Retrieving the missing dimension of statecraft: Religious faith in the service of peacebuilding. In: Johnstons, Douglas (ed.) Faith-Based Diplomacy: Trumping Realpolitik. Oxford: Oxford University Press, pp.231-58.

Archivo General de la Nación (no date a) Fondo Genovevo de la O: caja 122, exp. 2, p.17. Mexico City: Archivo General de la Nación.

Archivo General de la Nación (no date b) Fondo Genovevo de la O: caja 124, exp. 2, pp.36-7. Mexico City: Archivo General de la Nación.

Bailey, David C (1974) Viva Cristo Rey! The Cristero Rebellion and the Church-State Conflict in Mexico. Austin: University of Texas Press.

Barnett, Marguerite R (1976) The Politics of Cultural Nationalism in South India. Princeton, NJ: Princeton University Press.

Basedau, Matthias and Johannes Vullers (2010) Religion and armed conflict in sub-Saharan Africa, 1990 to 2008: Results from a new database. SGIR 7th Pan-European Conference on IR, Stockholm, Sweden, 9-11 September 2010.

Behuria, Ashok K (2010) The Islamist impulse haunting Pakistan. Strategic Analysis 35(1): 12-16.

Benford, Robert D and David A Snow (2000) Framing processes and social movements: An overview and assessment. Annual Review of Sociology 26: 611-39.

Billings, Dwight B (1990) Religion as opposition: A Gramscian analysis. American Journal of Sociology 96(1): $1-31$.

Boix, Carles (2003) Democracy and Redistribution. New York: Cambridge University Press.

Bourdillon, Michael FC (1976) The Shona Peoples: An Ethnography of the Contemporary Shona, with Special Reference to their Religion. Salisbury (Harare): Mambo Press.

Brading, David A (1975) Estructura de la Produccion Agricola en el Bajio, 1700 a 1850. Mexico City: Siglo Vientiuno Editores.

Brass, Paul (1997) Theft of an Idol. Princeton, NJ: Princeton University Press.

Brickhill, Jeremy (1995) Daring to storm the heavens: The military strategy of ZAPU, 1976-1979. In: Bhebe, Ngwabi and Terence Ranger (eds) Soldiers in Zimbabwe's Liberation War. London: James Currey, pp.48-72.

Brown, Judith M (1972) Gandhi's Rise to Power: Indian Politics, 1915-1922. Cambridge: Cambridge University Press.

Butler, Matthew (1999) The 'liberal' Cristero: Ladislao Molina and the Cristero Rebellion in Michoacán, 1927-1929. Journal of Latin American Studies 31(3): 645-71.

Butler, Matthew (2004) The church in 'red Mexico': Michoacán Catholics and the Mexican Revolution, 1920-1929. Journal of Ecclesiastical History 55(3): 520-41.

Butler, Matthew (2006) Revolution and the ritual year: Religious conflict and innovation in Cristero Mexico. Journal of Latin American Studies 38(3): 465-90.

Byers, Bruce A, Robert N Cunliffe and Andrew T Hudak (2001) Linking the conservation of culture and nature: A case study of sacred forests in Zimbabwe. Human Ecology 29(2): 187-218.

Dale, Stephen F (1977) The Islamic frontier in southwest India: The shahid as a cultural ideal among the Mappilas of Malabar. Modern Asian Studies 11(1): 41-55. 
Reid-Daly, Ronald and Peter Stiff (1982) Selous Scouts: Top secret war. Alberton, South Africa: Galago Publishing.

De Bonfil, Alicia OS (1966) Aspectos del Conflicto Religioso de 1926 a 1929: sus antecedentes y consecuencias. Mexico City: Instituto Nacional de Antropología e Historia.

De Juan, Alexander (2008) A pact with the devil? Elite alliances as bases of violent religious conflicts. Studies in Conflict and Terrorism 31(12): 1120-35.

De Juan, Alexander and Johannes Vullers (2010) Religious peace activism: The rational element of religious elites' decision-making processes. Working Paper No. 130. Hamburg: German Institute for Global and Area Studies (GIGA).

Eisinger, Peter K (1973) The conditions of protest behavior in American cities. American Political Science Review 67(1): 11-28.

Fabregas, Andres (1977) Los Altos de Jalisco: Caracteristicas generales. In: Diaz, Jose and Roman Rodriguez (eds) El Movimiento Cristero: Sociedad y Conflicto en los Altos de Jalisco. Mexico City: Nueva Imagen.

Fearon, James D and David D Laitin (2000) Violence and the social construction of ethnic identity. International Organization 54(4): 845-77.

Francis, W (1908) Imperial Gazetteer of India, Provincial Series: Madras. Vol. 2. Calcutta: Superintendent of Government Printing.

Franke, Wilmer (2002) The social construction of man, the state, and war: Identity, conflict and violence in the former Yugoslavia. New York, Routledge.

Franklin, Henry (1963) Unholy Wedlock: The Failure of the Central African Federation. London: Allen and Unwin.

Fry, Peter (1976) Spirits of Protest: Spirit Mediums and the Articulation of Consensus Amongst the Zezuru of Southern Rhodesia. Cambridge: Cambridge University Press.

Garcia, Jonathan and Richard G Parker (2011) Resource mobilization for health advocacy: AfroBrazilian religious organizations and HIV prevention and control. Social Science and Medicine 72(12): 1930-8.

Godwin, Peter and Ian Hancock (2008) Rhodesians Never Die. London: Pan Macmillan.

Gómez, Juan M. del Cid (2010) A financial profile of the terrorism of AL-Qaeda and its affiliates. Perspectives on Terrorism 4(4): 3-27.

Hank, Johnston and Jozef Figa (1988) The church and political opposition: Comparative perspectives on mobilization against authoritarian regimes. Journal for the Scientific Study of Religion 27(1): 32-47.

Hardgrave, Robert (1977) The Mappilla Rebellion, 1921: Peasant revolt in Malabar. Modern Asian Studies 11(1): 57-99.

Hasenclever, Andreas and Volker Rittberger (2003) Does religion make a difference? Theoretical approaches to the impact of faith on political conflict. In: Hatzopolous, Pavlos and Fabio Petito (eds) Religion in International Relations: The Return from Exile. New York: Palgrave Macmillan.

Hastings, Adrian (1997) The Construction of Nationhood: Ethnicity, Religion, and Nationalism. Cambridge: Cambridge University Press.

Hitchcock, RH (1925) A History of the Malabar Rebellion, 1921. Madras: Government Press.

Hubert, Cochet (1988) Ganadería y aparcería en la Sierra de Coalcomán. In: Cochet Hubert, Eric Léonard abd Jean Damien de Surgy (eds) Paisajes Agrarios de Michoacán. Zamora, Mexico: Colegio de Michoacán.

Keddie, Nikki R (1998) The new religious politics: Where, when, and why do fundamentalists appear? Comparative Studies in Society and History 40(4): 696-723.

Kenny, Michael (2004) The Politics of Identity: Liberal Political Theory and the Dilemmas of 'Difference'. Cambridge: Polity Press.

Kriger, Norma (1988) The Zimbabwe war of liberation: Struggles within the struggle. Journal of Southern African Studies 14(2): 304-22.

Krishnan, VVK (1993) Tenancy Legislation in Malabar, 1880-1970. New Delhi: Northern Book Centre.

Lampe, John R (2000) Yugoslavia as History: Twice there was a Country, 2nd edn. Cambridge: Cambridge University Press.

Lan, David (1985) Guns and Rain: Guerrillas and Spirit Mediums in Zimbabwe. Berkeley: University of California Press. 
Lan, David (1989) Resistance to the present by the past: Mediums and money in Zimbabwe. In: Parry, Jonathan and Maurice Bloch (eds) Money and Morality of Exchange. Cambridge: Cambridge University Press.

Latham, CJK (1986) Mwari and the divine heroes: Guardians of the Shona. MA Thesis, Rhodes University, South Africa.

Levi-Faur, David (2006) A question of size? A heuristics for stepwise comparative research design. In: Rihoux, Benoit and Heiki Grimm (eds) Innovative Comparative Methods for Policy Analysis: Beyond the Quantitative-Qualitative Divide. New York: Springer.

Lewy, Guenter (1974) Religion and Revolution. New York: Oxford University Press.

Logan, William (2004 [1887]) Malabar Manual. New Delhi: Asian Educational Services.

Lohman, Charles M and Robert I MacPherson (1983) Rhodesia: Tactical victory, strategic defeat. 7 June. Quantico, VA: Marine Corps Education and Development Command.

Mabry, Donald J (1978) Mexican anticlerics, bishops, Cristeros, and the devout in the 1920s: A scholarly debate. Journal of Church and State 20(1): 81-92.

McAdam, Doug (1982) Political Process and the Development of Black Insurgency. Chicago, IL: University of Chicago Press.

McAdam, Doug, Sidney Tarrow and Charles Tilly (2009) Comparative perspectives on contentious politics. In: Lichbach, Mark I and Alan S Zuckerman (eds) Comparative Politics: Rationality, Culture, and Structure. New York: Cambridge University Press, pp.260-90.

McCarthy, John D and Mayer N Zald (2006) The enduring vitality of the resource mobilization theory of social movements. In: Turner, Jonathan H (ed.) Handbook of Sociological Theory. New York: Springer, pp.533-65.

Machingura, Dzinashe and Mozambican Information Agency (1977) The Zimbabwe People's Army: An interview with Dzinashe Machingura. Issur: A Journal of Opinion 7(1): 15-18.

McKenna, Thomas M (1998) Muslim Rulers and Rebels: Everyday Politics and Armed Separatism in the Southern Philippines. Berkeley: University of California Press.

Marwell, Gerald and Pamela Oliver (1993) The Critical Mass in Collective Action: A Micro-Social Theory. Cambridge: Cambridge University Press.

Maxwell (1993) Local politics and the war of liberation in north-east Zimbabwe. Journal of Southern African Studies 19(3): 359-386.

Mazarire, G Chikozho (2011) Discipline and punishment in ZANLA: 1964-1979. Journal of Southern African Studies 37(3): 571-91.

Meredith, Martin (1980) The Past is Another Country: Rhodesia, U.D.I. to Zimbabwe. London: Pan Books.

Meyer, Jean (1974) Iglesia y el Estado, Vol. 3: Los Cristeros. Del Camino, AG (trans.). México City: Siglo Veintiuno Editores.

Meyer, Jean (1976) The Cristero Rebellion: The Mexican People Between Church and States, 1926-1929. Southern, Robert (trans.). Cambridge: Cambridge University Press.

Mill, John S (1859) Return to an Order of the House of Commons, dated 9th June, 1857, showing under what tenures, and subject to what land tax, lands are held under the several presidencies of India. In: Levi, Leone (ed.) Annals of British Legislation, Vol. IV. London: Smith, Elder and Co., pp.239-45.

Miller, Barbara (1984) The Role of Women in the Mexican Cristero Rebellion: Las señoras y las Religiosas. The Americas 40 (3): 303-323.

Montiel, Cristina J and Maria EJ Macapagal (2006) Effects of social position on societal attributions of an asymmetric conflict. Journal of Peace Research 43(2): 219-27.

Morris, Aldon D (1984) The Origins of the Civil Rights Movement. New York: Free Press.

Nair, C Gopalan (1923) The Moplah Rebellion, 1921. Calicut, Kerala: Norman Printing Bureau.

Navarro, Moises G (1985) La Confederación Nacional Campesina en la Reforma Agraria Mexicana. Ciudad de México: El Día en Libros.

Navarro, Moises G (2000-01) Cristeros y Agraristas en Jalisco, 2 Vols. Ciudad de México: El Colegio de México.

Oberschall, Anthony (1973) Social Conflicts and Social Movements. Englewood Cliffs, NJ: Prentice-Hall. 
Palley, Claire (1970) Law and the unequal society: Discriminatory legislation under the Rhodesian Front from 1963 to 1969, Pt. 1. Race and Class 12(1): 15-47.

Panikkar, KN (1978) Agrarian legislation and social classes: A case study of Malabar. Economic and Political Weekly 13(21): 880-8.

Panikkar, KN (1989) Against Lord and State: Religion and Peasant Uprisings in Malabar. New Delhi: Oxford University Press.

Polletta, Francesca and James M Jasper (2001) Collective identity and social movements. Annual Review of Sociology 27: 283-305.

Preston, Matthew (2004) Stalemate and the termination of civil war: Rhodesia reassessed. Journal of Peace Research 41(1): 65-83.

Purnell, Jennie (1999) Popular Movements and State Formation in Revolutionary Mexico: The 'Agraristas' and 'Cristeros' of Michoacán. Durham, NC: Duke University Press.

Ragin, Charles (1987) The Comparative Method: Moving Beyond Qualitative and Quantitative Strategies. London: University of California Press.

Randathani, Husain (2007) Mappila Muslims: A Study on Society and Anticolonial Struggles. Calicut, Kerala: Other Books.

Ranger, Terence (1985) Peasant Consciousness and Guerrilla War in Zimbabwe. Woodbridge: James Currey.

Ranger, Terence (1997) Violence variously remembered: The killing of Pieter Oberholzer in July 1964. History of Africa 24: 273-86.

Ratzinger, Joseph and Jurgen Habermas (2007) The Dialectics of Secularization: On Reason and Religion. San Francisco, CA: Ignatius Press.

Reich, Peter L (1997) The Mexican Catholic Church and constitutional change since 1929. Historian 60(1): $77-86$.

Sadomba, Zvakanyorwa W (2013) Personal interview, 5 May 2013. Harare, Zimbabwe.

Sanderson, Susan W (1984) Land Reform in Mexico: 1910-1980. Orlando, FL: Academic Press.

Sareen, Sushant (2010) Socio-economic underpinning of jihadism in Pakistan. Strategic Analysis 35(1): 6-11.

Scarnecchia, Timothy (2008) The Urban Roots of Democracy and Political Violence in Zimbabwe: Harare and Highfield, 1940-1964. Rochester, NY: University of Rochester Press.

Schoffeleers, JM (1978) Introduction. In: Schoffeleers, JM (ed.) Guardians of the Land: Essays on Central African Territorial Cults. Gwelo, Zimbabwe: Mambo Press, pp.i-xii.

Scott, James C (1976) The Moral Economy of the Peasant. New Haven, CT: Yale University Press.

Scott, James C (2009) The Art of Not Being Governed: An Anarchist History of Upland Southeast Asia. New Haven, CT: Yale University Press.

Smith, Anthony D (2003) Chosen Peoples: Sacred Sources of National Identity. Oxford: Oxford University Press.

Spierenburg, Marja (1995) The role of the Mhondoro cult in the struggle for control over land in Dande (northern Zimbabwe): Social commentaries and the influence of adherents. Occasional paper, Center for Applied Social Sciences. Harare: University of Zimbabwe.

Stern, Jessica (2000) Pakistan's jihad culture. Foreign Affairs, November-December.

Svensson, Isak (2007) Fighting with faith: Religion and conflict resolution in civil wars. Journal of Conflict Resolution 51(6): 930-49.

Tamayo, Jaime (2008) El Obregonismo y Los Movimientos Sociales: La Conformación del Estado Moderno en México (1920-1924). Guadalajara, Jalisco: Universidad de Guadalajara.

Thomas, EF (1921) Order under Section 144 C.P.C., District Magistrate of Malabar Calicut. 5 February 1921. Tilly, Charles (1978) From Mobilization to Revolution. Reading, MA: Addison-Wesley.

Toft, Monica D (2007) Getting religion? The puzzling case of Islam and civil war. International Security 31(4): 97-131.

Uadiale, Martin (2012) Implication of the political and economic factors in the rise of 'Boko Haram' insurgencies in Nigeria. International Journal of Advanced Legal Studies and Governance 3(3): 81-100.

United Kingdom (1963) Southern Rhodesia. Note by the First Secretary of State attaching memorandum prepared by the Central African Office, 3 April. The National Archives. 
United Kingdom (1966) Draft White Paper on Rhodesia. Note by the Secretary of State for Commonwealth Affairs, 23 November. The National Archives.

United Kingdom, Government of India (1903) Census of India, 1901. Vol. XV-A. Calcutta: Superintendent of Government Printing, India.

United Kingdom, Government of India (1913) Census of India, 1910. Vol. XII, Pt. 2. Calcutta: Superintendent of Government Printing, India.

Walker, Andrew (2012) What is Boko Haram? United States Institute of Peace, Special Report 308: 1-16. Washington, DC: USIP.

Washbrook, David (1973) Country politics: Madras 1880 to 1930. Modern Asian Studies 7(3): 475-531.

Wilkie, James W (1966) The meaning of the Cristero religious war against the Mexican Revolution. Journal of Church and State 8(2): 214-33.

Wilkinson, Steven I (2006) Votes and Violence: Electoral Competition and Ethnic Riots in India. New York: Cambridge University Press.

Williams, Robin M (1994) The sociology of ethnic conflicts: Comparative international perspectives. Annual Review of Sociology 20: 49-79.

Wood, Conrad (1987) Moplah Rebellion and its Genesis. New Delhi: People's Publishing House.

Woodward, Susan L (1995) Balkan Tragedy: Chaos and Dissolution After the Cold War. Washington, DC: Brookings Institution.

Yong, Tan T (2005) The Garrison State: The Military, Government and Society in Colonial Punjab, 1849 1947. New Delhi and Thousand Oaks, CA: Sage.

\section{Author biography}

Vasabjit Banerjee is a Post-Doctoral Fellow at Indiana University, USA and a Research Associate at the University of Pretoria, South Africa. Prior to this, he completed a post-doctorate at the University of Pretoria. His research interests are social movements, political violence, conflicts, regime formation, and foreign policy in South Asia, Latin America, and southern Africa. 